\title{
Saudi Young Females' Level of Knowledge Regarding Cervical and Breast Cancer
}

\author{
Magda Mohamed Mohamed Bayoumi*, Mona Mohamed Megahe d Elbas uny, \\ Afnan Mohsen Ahmed Nasser, Kholood Mohamed Abdullah, Noura Mohamed Ali Al mate ry
}

Nursing Department, College of Applied Medical Sciences Mohail Asser, King Khalid University

\begin{abstract}
Breast cancer is currently the top cancer in women in the entire world, the most common cancer site in the 13 administrative regions of Saudi Arabia was breast cancer the leading cancer among wo men. Cerv ical cancer ranks as the 2nd most frequent cancer in women between 15-44years of age. Incidence of cervical cancer in Saudi Arabia was 4.6 per 100.000 wo men. Our aim to evaluate level of knowledge regarding cervical and breast cancer among young females. A cross -sectional study was conducted from young females at science\& Art College and health science college. Interviewing structured questionnaire was used to collect data.; the questionnaire divided into three parts covered socio demographic data, breast cancer knowledge and cervical cancer knowledge among 215 students' with different age, parity and marital status were selected randomly. Out of 215 female student mean age was $22.6(9.4), 58 \%$ of study sample had unsatisfactory level of knowledge regard ing cervical and breast cancer, only $21.9 \%$ Know HPV vaccine, Television and radio were the most frequent $74.9 \%, 59.5 \%$ source of knowledge about breast and cervical cancer among study sample. In conclusion more efforts must be focused in provide proper education and reassurance our young females about danger health issues .
\end{abstract}

Keywords Level o Knowledge, Breast Cancer, Cervical Cancer

\section{Introduction}

Cancer is the leading cause of death worldwide and account for 7.6 million deaths around $13 \%$ of all deaths. Deaths from cancer are projected to continue to rise to cover 12 million in $2030 .{ }^{1}$ breast cancer is currently the top cancer in women in the entire world and the leading cancer killer among women aged 20-59 years in high-income countries compared to low and middle-income countries, but mortality is similar. It has been reported that each year, over 1.15 million wo men worldwide are diagnosed with breast cancer and $502,000 \mathrm{~d}$ ie from $\mathrm{d}$ is ease. $\mathrm{e}^{2,3}$

Saudi Arabia has total population 25,721,000 million, of which about 6million are expatriate. The population is overwhelmingly young, with $45.7 \%$ females. The total number of cancer cases analyzed among Saudis during the year 2004 was 6,969. Of those cases $50.1 \%(3,491)$ were reported among women. The most common cancer site in the 13 administrative regions of Saudi Arabia was breast cancer the leading cancer among wo men. ${ }^{1,4}$

Breast cancer largely viewed as a disease predominantly influenced by risk factors related to lifestyle, familial and

\footnotetext{
* Corresponding author:
}

mbayeome@kku.edu.sa (Magda Mohamed Mohamed Bayoumi)

Published online at http://journal.sapub.org/nursing

Copyright (C) 2012 Scientific \& Academic Publishing. All Rights Reserved genetic influences, hazardous effects of hormonal exposure, early age at menarche, late age at menopause, small number of children and nulliparity, late age at first birth, and no breast feeding have all been as sociated with an increased risk of developing breast cancer. ${ }^{5}$ early detection of breast cancer can lead to greater likehood of cure, the recommended early detection strategies are awareness of early signs and symptoms through screening by breast self-examination, clin ical breast examination, and mammography screening. ${ }^{6}$

Cervical cancer is the second common type of cancers among women in the world and also ranks as the $2^{\text {nd }}$ most frequent cancer in women between 15-44years of age as well as women of all ages in Asia. Incidence of cervical cancer in Saudi Arabia was 4.6 per 100.000 wo men. ${ }^{7}$

Cervical cancer is cancer of the uterine cervix. The ACS (American Cancer Society) estimated that over 12.000 cases of invasive cervical cancer diagnosed; approximately 3.000 of these women will die. Human papillomavirus (HPV) is a sexually transmitted infection, recognized as the necessary cause of $99 \%$ of all cervical cancers, other risk factors include: family history of cervical cancer, early sexual debut age, lack of regular Pap smear testing, as well as number of pregnancies. ${ }^{8}$

Awareness is the first step toward change and is a paramount importance. The aim of current study is to evaluate level of knowledge regarding cervical and breast cancer among young females. 


\section{Methodology}

\subsection{Study Design and Population}

This cross - sectional study was conducted from October 2011 to December 2011 among young females at science\& Art College and health science college, Mohaiel Asser, king Khalid University, Saudi Arabia. Study sample selected randomly. Total selected sample was 215 students' with different age, parity and marital status.

\subsection{Data Collection}

Interviewing structured questionnaire was used to collect data. It designed by researcherbased on the re lated literature, it tested for validity on twenty students who excluded from study sample. The study tool divided into three parts and covered the following items; part (1) socio demographic data (age, college, level, marital status, parity, history of cancer, and source of knowledge ...). Part (2) breast cancer knowledge (incidence in Saudi Arabia, risk factors, danger signs, screening, treatment).part (3) cervical cancer knowledge (hear about cervical cancer, risk factors, danger signs, HPV vaccine, pap smear, and treatment).Written consent was obtained from college dean and students verbal consent gotten individually to conduct study. Scoring system: The total knowledge score for total knowledge questions and sub questions (42), divided as: $0>26$ indicated unsatis factory knowledge and 26-42 indicated satisfactory knowledge.

\subsection{Data Analysis}

The collected data was analyzed using statistical package for social science (SPSS) version 15. Data were presented using descriptive statistics in the form of frequencies and percentages for qualitative variables.

\section{Results}

The total study sample was 215 female students, $66 \%$ were Science\& Art College students. Demographic characteristics of the study sample are presented in Table 1. The study sample mean age was $22.6(\mathrm{SD}+9.4)$, with the majority of them $177(82.3 \%)$ single; $192(89.3 \%)$ nulliparous. $5.6 \%$ have family history of breast cancer. $45.1 \%$ of study sample not hear before about cervical cancer.

As regard breast cancer knowledge Table 2. Clarified that simply $10.7 \%$ of study sample reported incidence of breast cancer in Saudi Arabia (10\%), 101(47.0\%) of them not considered breast cancer attack wo men only. In relation to breast cancer risk factors correct answers; the majority $80 \%$ consider breast feeding not risk factor and $60.5 \%$ consider fatter intake, 59.5\% smoking, 58.1\% genetic, and 55.8\% obesity were risk factors but only $35.3 \%, 26.0 \%$ respectively appreciate menopause and early menarche as major risk factors. Painless lump $(81.9 \%)$ and change in breast size $(73.5 \%)$ were the most frequent correct danger signs among study sample. $80.0 \%$ aware of breast self-exam as breast cancer screening method but only $29.3 \%$ aware of mammogram as the most screening method. more than two third(74.4) recommended surgery as a treatment for breast cancer.

Table (1). Participants' general Characteristics $(\mathrm{n}=215)$

\begin{tabular}{|c|c|c|}
\hline Items & No & $\%$ \\
\hline $\begin{array}{c}\text { College } \\
\text { Health sciences college } \\
\text { Science\& Art college }\end{array}$ & $\begin{array}{c}73 \\
142\end{array}$ & $\begin{array}{l}34.0 \\
66.0\end{array}$ \\
\hline $\begin{array}{c}\text { Age / year } \\
18-23 \\
24-29 \\
\text { Mean score }(\overline{\mathbf{X}}+ \\
\text { SD }) 22.6+9.4\end{array}$ & $\begin{array}{r}139 \\
76\end{array}$ & $\begin{array}{l}64.7 \\
35.3\end{array}$ \\
\hline $\begin{array}{c}\text { Marital status } \\
\text { Single } \\
\text { Married } \\
\text { Divorced } \\
\text { Widow }\end{array}$ & $\begin{array}{c}177 \\
34 \\
3 \\
1\end{array}$ & $\begin{array}{c}82.3 \\
15.8 \\
1.4 \\
0.5\end{array}$ \\
\hline $\begin{array}{c}\text { Parity } \\
\text { Nulliparous } \\
\text { From 1-5 } \\
\text { From 5-10 } \\
\end{array}$ & $\begin{array}{c}192 \\
21 \\
2\end{array}$ & $\begin{array}{c}89.3 \\
9.8 \\
0.9 \\
\end{array}$ \\
\hline $\begin{array}{c}\text { Family hist ory of breast cancer } \\
\text { Yes } \\
\text { No }\end{array}$ & $\begin{array}{c}12 \\
203\end{array}$ & $\begin{array}{c}5.6 \\
94.4\end{array}$ \\
\hline $\begin{array}{c}\text { Hear about cervical cancer } \\
\text { Yes } \\
\text { No } \\
\end{array}$ & $\begin{array}{r}118 \\
97 \\
\end{array}$ & $\begin{array}{l}54.9 \\
45.1 \\
\end{array}$ \\
\hline
\end{tabular}

Regarding study sample correct knowledge about cervical cancer, $67.9 \%$ and $61.4 \%$ respectively considering sexual disease and oral contraceptive risk factors while less than half $(49.8 \%)$ considered papillomavirus. $59.1 \%$ reported bleeding as danger sign whereas pelvic pain reported by $48.4 \%$. only $21.9 \%$ Know HPV vaccine however $64.7 \%$ believed that pap test help in cervical cancer early detection (Table 3).

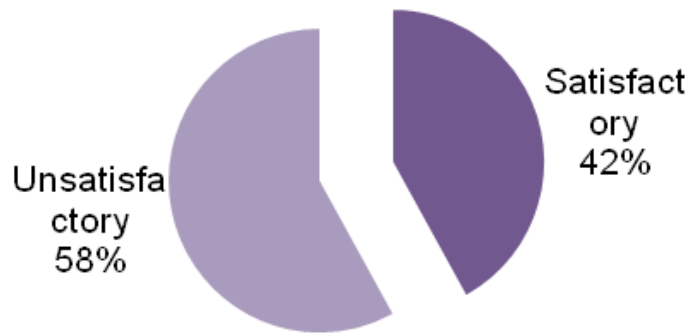

Figure 1. Pstticipants' level of knowledge regarding cervical and bteast cancer $(n=215)$

More than half (58\%) of study sample had unsatisfactory level of knowledge regarding cervical and breast cancer according to scoring while $42 \%$ had satisfactory knowledge Fig. (1). Television and radio were the most frequent $74.9 \%$, $59.5 \%$ source of knowledge about breast and cervical cancer followed by internet $57.7 \%, 47 \%$ while journals and magazines represented only $31.6 \%$ as a source cervical cancer information Fig. (2) 
Table (2). participants' knowledge regarding breast cancer $(n=215)$

\begin{tabular}{|c|c|c|}
\hline \multirow{2}{*}{ Items } & \multicolumn{2}{|c|}{ Correct answers } \\
\hline & No. & $\%$ \\
\hline Incidence of freast cancer in Saudi Arabia & 119 & 55.3 \\
\hline Breast cancer attack women only & 101 & 47.0 \\
\hline $\begin{array}{c}\text { Risk factors: } \\
\text { Genetic } \\
\text { Smoking } \\
\text { Big breast } \\
\text { Breast feeding } \\
\text { Obesity } \\
\text { More fat intake } \\
\text { Early menarche } \\
\text { Late menopause } \\
\text { Deliver first baby after30 } \\
\text { Cancer in other breast } \\
\text { Ovarian cancer } \\
\text { Exposure to x-ray } \\
\text { Oral contraception } \\
\text { Aging }\end{array}$ & $\begin{array}{c}125 \\
128 \\
54 \\
172 \\
120 \\
130 \\
56 \\
76 \\
87 \\
124 \\
105 \\
138 \\
119 \\
92\end{array}$ & $\begin{array}{l}58.1 \\
59.5 \\
25.1 \\
80.0 \\
55.8 \\
60.5 \\
26.0 \\
35.3 \\
40.5 \\
57.7 \\
48.8 \\
64.2 \\
55.3 \\
42.8\end{array}$ \\
\hline $\begin{array}{c}\text { Danger signs } \\
\text { Painless lymph } \\
\text { Inverted nipple } \\
\text { Change in breast size } \\
\text { Discharge or secretions } \\
\text { Change in breast skin } \\
\end{array}$ & $\begin{array}{c}176 \\
83 \\
158 \\
122 \\
143 \\
\end{array}$ & $\begin{array}{l}81.9 \\
38.6 \\
73.5 \\
56.7 \\
66.5 \\
\end{array}$ \\
\hline $\begin{array}{c}\text { Screening } \\
\text { Mammogram } \\
\text { Clinical breast examination } \\
\text { Breast self- examination } \\
\text { Biopsy } \\
\end{array}$ & $\begin{array}{c}63 \\
115 \\
172 \\
109 \\
\end{array}$ & $\begin{array}{l}29.3 \\
53.5 \\
80.0 \\
50.7 \\
\end{array}$ \\
\hline $\begin{array}{c}\text { Treatment } \\
\text { Hormonal therapy } \\
\text { Radiotherapy } \\
\text { Chemotherapy } \\
\text { Surgical }\end{array}$ & $\begin{array}{c}74 \\
86 \\
145 \\
160\end{array}$ & $\begin{array}{l}34.4 \\
40.0 \\
67.4 \\
74.4\end{array}$ \\
\hline
\end{tabular}

Table (3). Participants' knowledge regarding cervical cancer $(\mathrm{n}=215)$

\begin{tabular}{|c|c|c|}
\hline \multirow{2}{*}{ Items } & \multicolumn{2}{|c|}{ Correct answers } \\
\hline & No. & $\%$ \\
\hline $\begin{array}{c}\text { Risk factors: } \\
\text { Infect ion(papillomavirus) } \\
\text { Smoking } \\
\text { Sex early } \\
\text { Oral contraceptive pills } \\
\text { Family history } \\
\text { Sexual disease }\end{array}$ & $\begin{array}{c}107 \\
87 \\
101 \\
132 \\
104 \\
146\end{array}$ & $\begin{array}{l}49.8 \\
40.5 \\
47.0 \\
61.4 \\
48.4 \\
67.9\end{array}$ \\
\hline $\begin{array}{c}\text { Danger signs } \\
\text { Bleeding } \\
\text { Pelvic pain } \\
\text { Dyspareunia } \\
\text { Abnormal vaginal discharge }\end{array}$ & $\begin{array}{l}127 \\
104 \\
116 \\
119\end{array}$ & $\begin{array}{l}59.1 \\
48.4 \\
54.6 \\
55.4\end{array}$ \\
\hline Know about HPV vaccine & 47 & 21.9 \\
\hline Pap test help in early detection & 139 & 64.7 \\
\hline $\begin{array}{c}\text { Treatment } \\
\text { Radiotherapy } \\
\text { Chemotherapy } \\
\text { Surgical }\end{array}$ & $\begin{array}{c}96 \\
136 \\
140\end{array}$ & $\begin{array}{l}44.7 \\
63.3 \\
65.1\end{array}$ \\
\hline
\end{tabular}

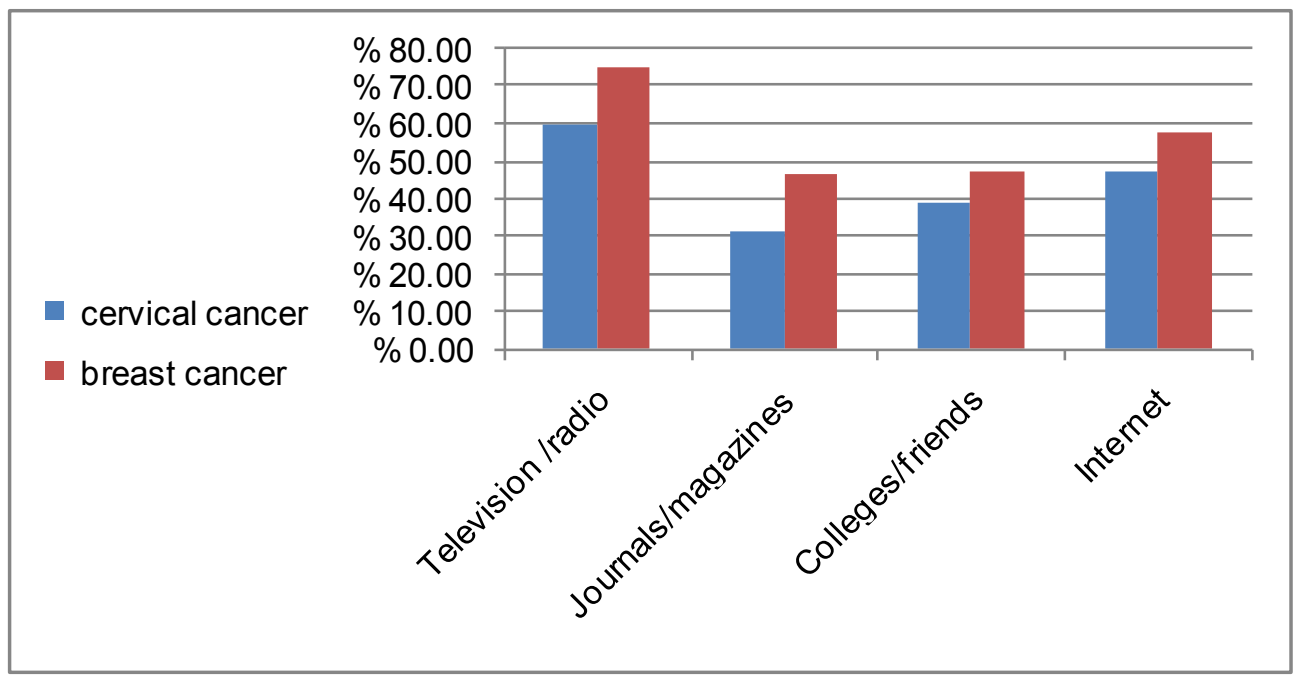

Figure 2. Participants ' source of informat ion regarding cervical and breast cancer $(\mathrm{n}=215)$ 


\section{Discussion}

Cancer incidence increases at faster rate with increasing age in young women, their cancers tend to be larger and higher grade with poorer prognostic characteristics, resulting in a higher risk of recurrence and death.9 Our study sample had a lack of knowledge about cervical and breast cancer, the most common cancers affected women in this young age, more than half of them had unsatisfactory level of knowledge. Previous studies confirmed our result. 10, 11

\subsection{Breast Cancer Knowledge}

The current study revealed that simply $10.7 \%$ of sample reported correct incidence of breast cancer in Saudi Arabia. Regard assessed risk factors in the present study the most frequent identified risk factor were family history, smoking and fatter intake, our result similar to study conducted in Malaysia among female university students. ${ }^{12}$ Less than one third considered big breast as a risk factor ofb reast cancer, in contrast of Iranian study carried out among women attending medical centers, ${ }^{13}$ young females in our study not appreciate menopause and early menarche as major risk factors, the same result reported by previous studies in different population. ${ }^{12,14}$ Aware of breast cancer danger signs improve breast cancer self-early detection and treatment, the majority of our sample reported painless lump and change in breast size as a most frequent signs while inverted nipple represented only one third, same result explained by other investigators. ${ }^{15,16}$ In the study conducted in Saudi Arabia among university female students aged from 18 to 39 year, only few women knew that nipple retraction $27.9 \%$ and nipple discharge $42.9 \%$ are warn ing signs of breast cancer. ${ }^{17}$ another study conducted among African American women the majority wo men aware that abnormal discharge from the nipple is a possible sign of breast cancer. ${ }^{18}$ Breast self-examination (BSE) is one of the important steps for identifying breast tumors at an early stage and has positive effect on the early detection, the American cancer society recommended breast self- examination to be performed monthly beginning at the age of twenty, ${ }^{19}$ more than two third indicate BSE most frequent breast cancer screening method, the same result showed by different studies. ${ }^{20,21,22}$ Mammogram is considered to be the forerunner in early detection of breast cancer but in the present study less than on third aware of mammogram as screening method. All breast cancer treatment alternatives identified by study sample. Undergoing surgery especially mastectomy involves loss of body part, however about two third of study sample choice surgery.

\subsection{Cervical Cancer Knowledge}

Cervical cancer is a major health problem, slightly half of our study sample heard about cervical cancer. Concerning cervical cancer risk factors, only $49.8 \%$ aware of HPV infection, however HPV recognized as the necessary cause of $99 \%$ of all cervical cancers. The same result reported in other studies among different population. ${ }^{23,24,25,26}$ Other risk factors frequently stated include sexual disease, oral contraceptives, and sex early. Similar to study conducted in Pakistan among interns. ${ }^{27}$ the most frequently cervical cancer symptoms was post coital bleeding, in the present study it reported by $59.1 \%$, this finding similar to other study. ${ }^{28}$ during the last years, two vaccines were markets to prevent cervical infection with human papilloma virus (HPV) world wide. ${ }^{29}$ Less than one third of our study sample know about HPV vaccine in contrast with study carried in Belgium among adult women (mean age 37 ). ${ }^{30}$ while another studies presentations show poor information about HPV vaccine. ${ }^{3132,33}$ Cervical cancer is largely preventable by effective screening programs and considerable reduction in cervical cancer incidence and deaths by systematic cytological smear screening programs. ${ }^{34}$ nearly two third in our present study aware of pap test as early detection screening method of cervical cancer. Similar result reported by previous studies. ${ }^{35,36,37}$

\subsection{Source of Infor mation}

Mass media was easily accessible and provide wide range of information, this explain our findings that mass media represented the most common source of information for cervical and breast cancers among present participants, similar findings were reported in previous studies. ${ }^{38,39,40}$ Followed by colleges and friends in contrary with other researchers who found that the main source of information was friends and colleagues. ${ }^{41}$

\section{Conclusions}

Overall, there is limited knowledge regarding cervical and breast cancer among university female students. Furthermo re they not aware of screening programs for cancer early detection or HPV vaccine to prevent cervical cancer. More efforts must be focused in provide proper education and reassurance our young females about danger health issues. Posters and pamphlets in the university campus should be developed to increase heath awareness, and implemented educational programs as a part of extracurricular activities.

\section{ACKNOWLEDGEMENTS}

This scientific research was funded by centre of talent and creativity, king Khalid university.

\section{REFERENCES}

[1] World Health Organization: Cancer. (http://www.who.int/me dia center/factsheets/fs279/en). Accessed 30.07.2009.

[2] United States Cancer Statistics (2007) incidence and mortality, http://www.cdc.gov/cancer/npcr/npcrpdfs/US cancerstatistics2004incidenceand mortality.pdf. 
[3] World Health Organization: Cancer (2011) (http://www.who .int/media center/factsheets/fs279/en). Accessed 30.07.2011.

[4] The national cancer registry. Cancer incidence report, Saudi Arabia.2005 (cited Oct 15, 2007): available from: htt://www. kfshrc.edu.sa/NCR/.

[5] Albrektsen G, Geuch I, Hasen S., Kvale G., (2005): Breast cancer risk by age at birth, time since birth and time intervals between birth; exploring interaction effects. $\mathrm{Br} \mathrm{J}$ cancer ;92:167-75.

[6] Coleman M.P, et al (2008): Cancer survival in five Continents: a worldwide population- based study (CONCORD).Lancet Oncol Journal, 9:730-56.

[7] WHO (2007): HPV and cervical cancer in the world 2007 report, volume 25, supplement 3, 1 November.

[8] American cancer society (2009) available at. http://www.cancer.org/docroot/CRI/content 242x: do we know what causes cervical cancer

[9] Yankaskas, B.C. (2006): Epidemiology of breast cancer in young women, Breast Disease Journal, volume23.

[10] Galeeder N. (2001): Determination of knowledge and attitudes of female teachers about breast self-examination in Korramabad. Urmia Medical Journal, 1:347- 349.

[11] Chong P.N., Krishnan M., Hong C.Y., et al (2002): Knowledge and practice of breast cancer screen ing amongost public health nursrs in Singapore. Singapore Med J.34 (10):509-516.

[12] Hadi M.M., Hassali M.A., Shafie, A.A., Awaisu, A.(2010): Evaluation of breast cancer awareness among female university students in Malaysia, Pharmacy Practice, Jan-Mar;8(1):29-34.

[13] Parsa P., Kandiah M.,(2005) : Breast cancer knowledge, perception and self -examination practices among Iranian women, International Medical Journal, Vol.4 No. 2.

[14] Grunfeld E.A., Ramirez A.J., Hunter M.S., Richards M.A.,(2002): Women's knowledge and beliefs regarding breast cancer; 86:1373-1378.

[15] Okobia M.N, Bunker C.H, Okonofua F.E Osime U, (2006): Knowledge, attitude and practice of Nigerian women towards breast cancer: cross- sectional study. World J Surg Oncol Feb $21 ; 4: 11$.

[16] Kashgar R.H, Ibrahim A.M(1996): Breast cancer: attitude, knowledge and practice of breast self -examination of 157 Saudi woman. Journal of Family and Community Medicine; $3(1): 10-12$.

[17] Habib F, Salman S, Safwat M, Shalaby S.,(2010): Awareness and knowled ge of breast cancer among university students in Al Madina Al Munawara region, Middle East Journal of cancer;1(4):159-166.

[18] Powe B., Daniels E., Finnine R., Thompson A., (2005): Preceptions about breast cancer among aferican American women: do selected educational materials challengs them? Patient education and counseling.56 (2):197-204.

[19] Aina, N.,(2008): Cancer patient registery- breast cancer (NCPR- breast cancer. Med J Malaysia. Sep;63 suppl c:72-3.

[20] Lam WW, Chan C.P., Chan C.F., Mak C.C, et al (2008):
Factors affecting the palpability of breast lesion by breast self-examination. Sin gapore Med J ;49(3):228-32.

[21] Montazeri A, Khaleghi F, Haririchi I, et al (1999): Breast self-examination in Iran: a population - based study. Cancer strategy: 1:191-194.

[22] Mittra I,(1999): Clinical breast examination as a global strategy for breast cancer. Cancer strategy.1:152-156.

[23] Nganwai P, TruadponP, Inpa C, San gpetngam B, et al(2008): knowledge, attitudes and practices vis-à-vis cervical cancer among registerd nurses at the faculty of medicine, knon kaen university, Thailand. Asia Pac J Cancer Prev 9:15-18.

[24] Lee P.W, Kwan T.T, Tam K.F, Chan K.K, Young P.M, et al(2007): Beliefs about cervical cancer and human papillomavirus(HPV) and acceptability of vaccination among Chinese women in hung kong. Prv Med 45:130-134.

[25] Mosavel M, El- Shaarawi N, (2007): I have never heard that one": young girl' knowled ge and perception of cervical cancer. J Health Commun 12:707-719.

[26] Vrscaj M.U, Vakselj A, Strzinar V, Bebar S, Baskovic M, et al(2008): knowledge about and attitude to Pap smears, cervical cancer and human papillomavirus among women in Slovenia. Eur J Gyanecol Oncol 29:148-153.

[27] FaizenS, Ayub S, Manzoor N.F, Azim S, et al (2010): Knowledge and awareness about cervical cancer and its prevention amongst interns and nursing staff in tertiary care hospitals in Karachi, Pakistan, Plos ONE 5(6):e11059.

[28] Shapley M, Jordan J, Croft P.R, (2006): A systematic review of post coital bleeding and risk of cervical cancer. Br J Gen Pract 56:453-460.

[29] Herzog T.J, Huh W.K, Downs I.S, Monk B.J, (2008): Initial lessons learned in HPV vaccination, Gynecol Oncol; 109:54-11.

[30] Donders, G.G, Bellen G, Declerq A, Berger J, et al (2009): Change in knowled ge of women about cervix cancer, human papilloma virus (HPV) and vaccination due to introduction of HPV vaccines, Euro J Obstet Gynecol.

[31] Hanisch R, GustatJ, Hagensee ME et al(2007): knowledge of pap screening and human papillomavirus among women attainding clinica in Medellin, Colombia.int $\mathrm{j}$ gynecol cancer.

[32] Donders G.G, Gabrovska M, Bellen G. et al,(2008): Knowledge of cervix, human papillomavirus and vaccination at rhe moment of introduction of the vaccine in women in Belgium. Arch Gynecol Oobstet 277:291-298.

[33] Rosenthal D, Dyson S, Pitts M, Garland S, (2007): Challenges to accepting a human papillomavirus (HPV) vaccine: a qualitative study of Australian women. Women health 45:59-73.

[34] Wong L.P, Wong Y.L, Low W.Y, et al (2009): Knowledge and awareness of cervical cancer and screening among Malaysian women who have never had a pap smear: a qualitative study, Singap ore Med J; 50(1):49.

[35] Gessouli- Voltyraki E, Tsetsekou E, Metaxa A, et al (2010): The knowledge of women in a Greek province regarding the cervical cancer, its prevention capabilities and the pap test, Health Science Journal volume 4, issue 2.

[36] Lin S.J (2008): Factors influencing the uptake of screening 
services for breast and cervical cancer in Taiwan, J R Soc Health; 128(6):327-34.

[37] Hoque E, Hoque M.,(2009): Knowledge of and attitude towards cervical cancer among female university students in south Africa. South Afr J Epidemiol Infect; 24(1).

[38] Tan Y.Y, Heshman R, Qodriyah H.M,(2010): Knowledge and attitude of university students in health science on the prevention of cervical cancer, Med J Malaysia Vol 65 No 1.
[39] Grend M.A, Magloire Z.F, (2008): Awareness, knowledge, beliefs about human papillomavirus in a racially adverse sample of young adults, J Addesc Health; 42:237-42.

[40] Somadatta P., Baridalyne N.,(2008): Awareness of breast cancer in women of an urban resettlement colony, Indian $\mathrm{J}$ Cancer ; 45:194-53.

[41] Rizwan M.M, Saadullah M, (2009): lack of awareness about breast cancer and its screening in developed countries, Indian J Cancer; 46:252-3. 